\title{
The Ontogeny of Brain Receptors for Corticotropin-Releasing Factor and the Development of Their Functional Association with Adenylate Cyclase
}

\author{
Thomas R. Insel,, ${ }^{1}$ George Battaglia, ${ }^{2}$ David W. Fairbanks, ${ }^{1}$ and Errol B. De Souza ${ }^{2}$ \\ 'Section on Comparative Studies of Brain and Behavior, Laboratory of Clinical Science, NIMH, Poolesville, Maryland \\ 20837, and ${ }^{2}$ Neuroscience Branch, Addiction Research Center, NIDA, Baltimore, Maryland 21224
}

\begin{abstract}
This study reports the ontogeny of corticotropin-releasing factor (CRF) receptor binding sites in rat brain, using both membrane binding assays and in vitro receptor autoradiography. CRF binding sites are evident by prenatal day 17 , increase to $312 \%$ of their adult density by postnatal day 8 , then decrease to reach adult values by day 21 . Not only the density, but the distribution of CRF binding undergoes major modifications in development. CRF binding sites are most numerous in striatum prenatally, but postnatally, binding is more dense in the cortex, reaching the adult laminar distribution by postnatal day 14. Brain CRF receptors are linked to adenylate cyclase early in postnatal life. This contrasts with the later appearance of most of the guanine nucleotide stimulatory protein and catalytic subunit sites in the rat brain and suggests that CRF receptors may become functional earlier than several other brain receptors that are linked to adenylate cyclase.
\end{abstract}

Corticotropin-releasing factor (CRF) is a 41 -amino-acid peptide that has been isolated from ovine hypothalami (Vale et al., 1981) and been demonstrated to release proopiomelanocortin (POMC)derived peptides from the anterior and intermediate lobes of the rat pituitary gland (reviewed in Vale et al., 1983, and De Souza et al., 1985a, b). In addition to its endocrine role at the pituitary, CRF has been shown to have broader roles within the CNS. The peptide is widely distributed in brain regions outside of the hypothalamus (Cummings et al., 1983; Swanson et al., 1983); central administration of CRF to rodents and primates has been associated with robust autonomic (Brown et al., 1982; Tache et al., 1983; Insel et al., 1984) and behavioral (Britton et al., 1982; Sutton et al., 1982; Kalin et al., 1983) effects; and receptors for CRF have been characterized and localized in brain (De Souza et al., 1984; Wynn et al., 1984; Chen et al., 1986; De Souza, 1987). Taken together, these studies have suggested that CRF is a neurotransmitter with a CNS role, consistent with its pituitary effects, of integrating the organism's response to stress. This hypothesis is further supported by several observations at the cellular level, including the demonstration of CRF release from brain slices in a calcium-dependent manner following potassium stimulation (Smith et al., 1985), increased

Received Sept. 25, 1987; revised Feb. 1, 1988; accepted Feb. 16, 1988.

Correspondence should be addressed to Thomas R. Insel, M.D., Laboratory of Clinical Science, NIMH, NIH Animal Center, P.O. Box 289, Poolesville, MD 20837.

Copyright $(1988$ Society for Neuroscience $0270-6474 / 88 / 114151-08 \$ 02.00 / 0$ neuronal firing after iontophoretic application of CRF (Aldenhoff et al., 1983; Valentino et al., 1983), and stimulation of adenylate cyclase in brain homogenates following incubation with CRF (Wynn et al., 1984; Chen et al., 1986; Battaglia et al., 1987).

Very little is known about the developmental aspects of CRF's endocrine and behavioral effects. Ontogenetic studies of the hypothalamic-pituitary-adrenal (HPA) axis in the developing rat have demonstrated a stress-nonresponsive period during the first 2 weeks of postnatal life (reviewed in Sapolsky et al., 1986; Walker et al., 1986a). Pituitary receptors for CRF are functional well before birth (Dupouy and Chatelain, 1984), but soon after birth the pituitary shows a time-limited, exaggerated negative feedback sensitivity to glucocorticoids (Walker et al., 1986b). This enhanced sensitivity to glucocorticoids appears to dampen both the basal and stress-induced adrenocorticotropic hormone (ACTH) and corticosterone responses to CRF (Walker et al., 1986b). The exaggerated corticotroph sensitivity to glucocorticoids in early neonatal life may explain, in part, the low levels of ACTH following peripheral CRF (Walker et al., 1986a) and glucocorticoid (Walker et al., 1986b) administration; however, the mechanism by which other stressors, such as urethane and prolonged social isolation, can elicit a robust HPA response throughout this generally nonresponsive period (Walker et al., $1986 \mathrm{~b}$; Stanton et al., 1987) is unclear.

Differences in the HPA response to various stressors during development could be due to the area proximal to the pituitary in central CRF pathways. CRF has been detected in the median eminence as early as day 18 of fetal life (Bugnon et al., 1982, 1984). Although CRF immunoreactivity in the medium eminence appears to decrease at birth, it rccovers within the first postnatal day (Bugnon et al., 1982). During the first postnatal week, basal levels of CRF in hypothalamus appear to be only about $20 \%$ of adult levels (Walker et al., 1986a). An early study using a bioassay for CRF found a decreased CRF response to stress during the first postnatal week (Hiroshige and Sato, 1971). Thus, during the stress-nonresponsive period, in addition to decreased pituitary responsiveness to CRF, there appears to be a decreased hypothalamic content of CRF and perhaps reduced release with respect to certain stressors.

Extrahypothalamic CRF pathways, believed to integrate the neural response to stress, have not yet been studied with respect to development. Presumably, delayed maturation of extrahypothalamic CRF neurons or CRF receptors might also contribute to the stress-nonresponsive period and provide an explanation for the robust HPA response to some stressors but not 
to others. Although the ontogeny of pituitary CRF receptors has recently been described (Walker et al., 1986a), the development of brain CRF receptors might be expected to follow an independent time course, as the brain and pituitary receptors are regulated separately in adulthood (De Souza et al., 1985b).

In the present study, we investigated the density, pattern of distribution, and second-messenger coupling of CRF receptors in the developing rat brain. In addition to describing the developing pattern of brain CRF receptors, we describe the ontogeny of the activities of the guanine nucleotide regulatory protein $\left(G_{s}\right)$ and of the catalytic subunit believed to mediate the intracellular response to $\mathrm{CRF}$ receptor activation.

\section{Materials and Methods}

Subjects. Sprague-Dawley females were obtained when 10-14 d pregnant (Taconic Farms, NY). Fetal brains were removed following C-section at days $15,17,19$, and 21 of pregnancy (E15, E17, E19, E21), placed for $5 \mathrm{~min}$ in ice-cold $10 \%$ sucrose, then frozen on dry ice and stored at $-80^{\circ} \mathrm{C}$ until assay. Postnatal brains, removed following decapitation of pups at ages $2,8,14,21$, and $28 \mathrm{~d}$ postbirth (P2, P8, P14, P21, P28), were handled in the same manner. For postnatal ages, day of birth was considered day 0 . For comparison to brain receptors, pituitaries of a few animals were also removed and frozen.

$C R F$ receptor binding. CRF receptor binding in brain homogenates was carried out as described previously (De Souza, 1987). Brain tissue from each age group was homogenized in 30 volumes of ice-cold buffer ( $50 \mathrm{~mm}$ Tris- $\mathrm{HCl}, 10 \mathrm{~mm} \mathrm{MgCl}_{2}, 2 \mathrm{~mm}$ EGTA, pH 7.2 at $22^{\circ} \mathrm{C}$ ) using a Brinkman Polytron (setting of 5 for $20 \mathrm{sec}$ ) and centrifuged at 48,000 $\times g$ for $10 \mathrm{~min}$ at $4^{\circ} \mathrm{C}$. The resulting pellet was washed once in buffer, recentrifuged at $48,000 \times g$ for $30 \mathrm{~min}$ at $4^{\circ} \mathrm{C}$, then resuspended in the same buffer to a final tissue concentration of $20-40 \mathrm{mg}$ wet weight $/ \mathrm{ml}$ buffer. Protein concentrations were determined according to the method of Lowry et al. (1951). Incubation was carried out in a $1.5 \mathrm{ml}$ polypropylene microtube containing $100 \mu \mathrm{l}$ of ${ }^{125} \mathrm{I}$-Tyr ${ }^{0}$-ovine CRF (New Fngland Nuclear, Boston, MA; act, $2200 \mathrm{Ci} / \mathrm{mmol}$ ) at a concentration of approximately $40,000 \mathrm{cpm} / 100 \mu \mathrm{l}$ in incubation buffer, and with 100 $\mu \mathrm{l}$ of either incubation buffer or $3 \mu \mathrm{M}$ unlabeled rat/human CRF (rCRF) (Peninsula, San Carlos, CA) (final concentration, $1 \mu \mathrm{M}$ rCRF) for defining nonspecific binding. Incubation buffer consisted of $50 \mathrm{mM}$ Tris- $\mathrm{HCl}, 10$ $\mathrm{mM} \mathrm{MgCl}_{2}, 2 \mathrm{~mm}$ EGTA, $0.15 \%$ BSA, $0.15 \mathrm{~mm}$ bacitracin, and aprotinin $(150 \mathrm{~K} \mathrm{IU} / \mathrm{ml})$, with $\mathrm{pH}$ of 7.2 at $22^{\circ} \mathrm{C}$. After a $2 \mathrm{hr}$ incubation at room temperature, tissue was separated by centrifugation for $3 \mathrm{~min}$ at 12,000 $x g$. The resulting pellet was washed gently with $1 \mathrm{ml}$ of ice-cold PBS containing $0.01 \%$ Triton, and recentrifuged at $12,000 \times g$ for $3 \mathrm{~min}$. The supernatant was aspirated and the radioactivity of the pellet was counted in a gamma counter at $80 \%$ efficiency.

Autoradiographic binding was measured on slide-mounted $16 \mathrm{M} \mathrm{sec}$ tions, as previously reported (De Souza et al., 1985a). Endogenous CRF was removed by prewashing all slide-mounted tissue sections for 30 min in the same buffer used for homogenization, as described above. Incubation was carried out in the presence of $0.1 \mathrm{nM}^{125}{ }^{12}-\mathrm{Tyr}^{0}$-ovineCRF, with nonspecific binding determined in adjacent sections by adding $1 \mathrm{M}$ unlabeled rCRF. Following a $2 \mathrm{hr}$ incubation, all slides were washed for $5 \mathrm{~min}$ in ice-cold PBS, dried under a stream of cold air, and then apposed to ${ }^{3} \mathrm{H}$ Ultrofilm (LKB) for $48 \mathrm{hr}$ at $4^{\circ} \mathrm{C}$ prior to development. Autoradiograms were analyzed for regional optical density using the Loats Image Analysis Program (Amersham).

Adenylate cyclase measurement. Adenylate cyclase assays were carried out as previously described (Battaglia et al., 1987). Briefly, the tissues were prepared as described above for the CRF receptor binding assay. The assay was carried out at $37^{\circ} \mathrm{C}$ for $10 \mathrm{~min}$ in $200 \mu$ liters of buffer containing $100 \mathrm{~mm}$ Tris- $\mathrm{HCl}, 10 \mathrm{~mm} \mathrm{MgCl}, 0.4 \mathrm{~mm}$ EGTA, $0.1 \% \mathrm{BSA}$, $1 \mathrm{mM}$ isobutylmethylxanthine (IBMX), phosphocreatine kinase (250 $\mathrm{U} / \mathrm{ml}$ ), $5 \mathrm{~mm}$ creatine phosphate, and $0.8 \mathrm{mg}$ wet weight of tissue (approximately $50 \mu \mathrm{g}$ protein). Guanosine 5 '-triphosphate (GTP) $(100 \mu \mathrm{M})$, $10 \mathrm{~nm}$ forskolin, $20 \mathrm{mM} \mathrm{NaF}$, and/or $1 \mu \mathrm{M} \mathrm{rat} /$ human $\mathrm{CRF}$ were added to appropriate tubes. Reactions were initiated by the addition of substrate (1 mm ATP/32P-ATP) (approximately $2-4 \mathrm{Ci} /$ tube) and stopped by addition of $100 \mu \mathrm{l}$ of $50 \mathrm{~mm}$ Tris- $\mathrm{HCl}, 45 \mathrm{~mm}$ ATP, and $2 \%$ SDS. One milliliter of ${ }^{3} \mathrm{H}$-cAMP (approximately $40,000 \mathrm{dpm} / \mathrm{sample}$ ) was added to each tube to monitor the recovery of cAMP, and the separation of ${ }^{32} \mathrm{P}$-cAMP from ${ }^{32} \mathrm{P}$-ATP was accomplished by sequential elution over Dowex and alumina columns. Recovery was consistently greater than $80 \%$.

\section{Results}

In homogenate binding studies (Table 1, Fig. 1), CRF receptors are detectable by day E17 at a level of about $40 \%$ of that found in a day P28 animal (i.e., adult rat). Binding to CRF receptors increases rapidly to exceed adult levels within $2 \mathrm{~d}$ time and continues to increase until day $P 8$, when the amount of binding is $312 \%$ of the $\mathrm{P} 28$ level. Following this peak in receptor density, binding decreases until day $\mathrm{P} 21$, when the values are comparable to those at day P28.

To determine whether these changes in the amount of binding reflect developmental changes in the number or the affinity of CRF receptors, saturation studies were performed in wholebrain homogenates from P8 and P28 animals using 8 concentrations of ${ }^{125} \mathrm{I}-\mathrm{Tyr}^{0}$-ovine CRF (0.01-1.0 nM). Scatchard analysis revealed a difference in receptor number $\left(B_{\max }=97.8 \pm\right.$ $1.2 \mathrm{fmol} / \mathrm{mg}$ protein in the P8 brain compared to $36.7 \pm 22.1$ $\mathrm{fmol} / \mathrm{mg}$ protein in the P28 brain). Affinities were similar at both ages $\left(K_{\mathrm{d}}=0.28 \pm 0.09 \mathrm{nM}\right.$ and $0.17 \pm 0.09 \mathrm{nM}$ for P8 and $\mathrm{P} 28$, respectively), and approximated previously reported values for adult brain (De Souza, 1987).

Specific binding of ${ }^{125}$ I-Tyr ${ }^{0}$-ovine CRF in slide-mounted brain sections is evident as early as day E15. In autoradiographic studies, CRF binding increases in intensity throughout the subsequent $6 \mathrm{~d}$ prior to birth, with highest densities present in the striatum, especially at the head of the caudate (Fig. 2, $A-F$ ). Nonspecific binding is low throughout this period. Specific binding in the neocortex is not present until $2 \mathrm{~d}$ after birth, increases in intensity and distribution from day $\mathrm{P} 2$ on, and, by day P8, binding appears diffusely through the cortex (Fig. 2, E, F). As binding in cortex increases, binding to striatum becomes progressively less dense (Fig. 3). The laminar localization of CRF receptors primarily to layer IV of cortex, as observed in adult animals, can be seen by day Pl4 (Fig. $2, G-I$ ). Other areas of intense binding in the adult, such as amygdala and claustrum, are not cvident until day P14. Marked ${ }^{125} \mathrm{I}-\mathrm{Ty}^{\mathrm{n}}$-ovinc-CRF binding to pituitary is evident as early as E17, at a time when binding to brain is just detectable (Fig. 2, $J-L$ ).

As shown in Table 1 and Figure 1, the CRF-stimulated adenylate cyclase activity, computed either as absolute activity or as a percentage of day 28 values, is present but very low at day E17. CRF-stimulated adenylate cyclase activity rises sharply to about two-thirds the adult levels in fetal brain and reaches adult levels by the second day after birth. As observed for the development of CRF receptors, there is an overshoot of CRFstimulated adenylate cyclase activity above adult levels in the second postnatal week (day P14); the CRF receptor-stimulated adenylate cyclase activity at day $\mathbf{P} 21$ is comparable to values seen at day $\mathrm{P} 28$.

We have compared the ontogeny of CRF receptors with CRFstimulated adenylate cyclase activity and defined a relationship between the 2 parameters by determining the CAMP (in fmol) produced per $\mathrm{min} / \mathrm{fmol} \mathrm{CRF}$ receptor, which we call the "CRF activity index." This measure provides an index of the percentage of CRF receptors coupled in a stimulatory manner to the catalytic subunit. As shown in Table 1, a greater, but comparable, proportion of the existing CRF receptor population appears to be involved in the stimulation of adenylate cyclase activity from day $\mathbf{P} 14$ to $\mathbf{P} 28$ than at any of the earlier time points examined, as reflected by the marked differences in the 
Table 1. Ontogeny of CRF receptors and CRF-stimulated adenylate cyclase activity in homogenates of whole rat brain ${ }^{a}$

\begin{tabular}{lcll} 
& & $\begin{array}{l}\text { CRF-stimulated } \\
\text { activity above } \\
\text { basal } \\
\text { (pmol cAMP/ } \\
\text { min/mg protein) }\end{array}$ & $\begin{array}{l}\text { CRF activity } \\
\text { index } \\
\text { (fmol cAMP/ } \\
\text { min/fmol CRF } \\
\text { receptors) }\end{array}$ \\
Age & $\begin{array}{l}\text { CRF receptors } \\
\text { (fmol/mg protein) }\end{array}$ \\
\hline E17 & $20.6 \pm 1.3$ & $1.25 \pm 0.05$ & 60.7 \\
E19 & $63.1 \pm 1.7$ & $28.1 \pm 5.7$ & 352 \\
E21 & $79.8 \pm 2.3$ & $26.6 \pm 3.8$ & 333 \\
P2 & $94.6 \pm 2.0$ & $40.3 \pm 0.7$ & 426 \\
P8 & $150.1 \pm 7.5$ & $36.4 \pm 1.7$ & 242 \\
P14 & $82.6 \pm 6.5$ & $64.8 \pm 3.4$ & 784 \\
P21 & $55.7 \pm 3.4$ & $36.6 \pm 3.4$ & 657 \\
P28 & $48.1 \pm 3.5$ & $42.3 \pm 6.1$ & 879 \\
\hline
\end{tabular}

$\bar{a}$ In homogenates of whole rat brain, CRF receptors were determined using 0.1 nim ${ }^{125}$ I-Tyr ${ }^{\circ}$-ovine CRF and CRF-stimulated adenylate cyclase activity was determined using $1 \mu \mathrm{M}$ rat/human CRF, as described in Materials and Methods. Data represent the mean and SEM from $2-4$ animals at each time point. Specific CRF receptor binding represented approximately $80 \%$ of totals, while CRFstimulated adenylate cyclase activity ranged from 10 to $35 \%$ above basal $(+100$ $\mu_{\mathrm{M}}$ GTP) activity.

values of the "CRF activity indices" noted between earlier (before day P14) and later (post-P14) time points. The degree of coupling of CRF receptors with the catalytic subunit in a stimulatory manner, therefore, is independent of the absolute number of CRF receptors present.

To determine whether coupling of CRF receptors to adenylate cyclase varies in a regionally specific fashion through ontogeny, we have compared striatum and cortex at P3 and P30. This analysis was of particular interest because CRF receptors in striatum are more abundant at P3 than later, while the opposite pattern holds for cortex. Are the transiently expressed CRF receptors in striatum linked to cyclase? As shown in Table 2, 1 $\mu \mathrm{M}$ CRF ( $+\mathrm{GTP})$ increased adenylate cyclase production above GTP-stimulated levels in striatum and cortex at both ages. The percentage incrcase in striatum, however, was relatively low at both ages $(18.0 \pm 3.3 \%$ and $6.9 \pm 3.5 \%$ at $\mathrm{P} 3$ and $\mathrm{P} 30$, respectively) compared to cortex $(56.9 \pm 2.5 \%$ and $51.4 \pm 3.1 \%$ at P3 and P30, respectively). As noted earlier (Fig. 3), CRF receptors are equally dense in striatum and cortex at $\mathrm{P} 3$, so this regional difference in CRF stimulation of adenylate cyclase suggests that relatively few striatal CRF receptors are linked to this second messenger.

Since any investigation of the ontogeny of CRF-stimulated adenylate cyclase activity is dependent on the presence of both a functional catalytic subunit and the stimulatory guanine nu-

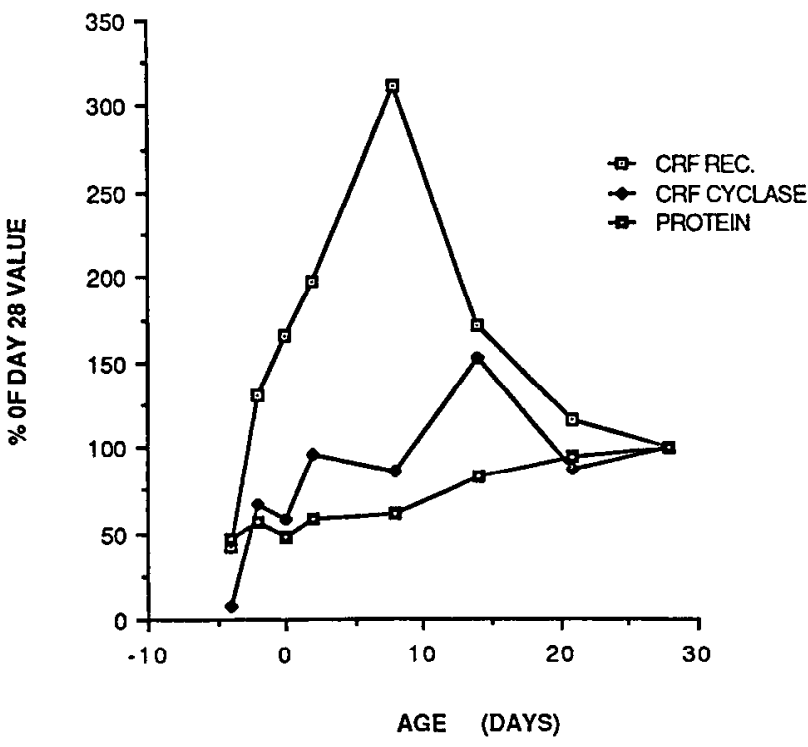

Figure 1. Development of ${ }^{125}$ I-Tyr $^{0}$-oCRF-specific binding, CRF stimulation of adenylate cyclase activity, and protein concentration from E17 (4 d prior to birth) to P28 ( $28 \mathrm{~d}$ postbirth) in whole rat brain homogenates. Data are expressed as percentages of $\mathrm{P} 28$ values. Absolute values are given in Table 1.

cleotide regulatory protein $\left(G_{s}\right)$, we have assessed the development of the activity of these components in homogenates of pre- and postnatal whole rat brain. As shown in Table 3, as early as day E17 the catalytic subunit appears to be capable of cAMP production (34.8 $\mathrm{pmol}$ cAMP per $\mathrm{min} / \mathrm{mg}$ protein). In addition, at this early time point the enzyme can be directly stimulated by forskolin (11.4-fold), as well as activated by GTP (2.3-fold) and $\mathrm{NaF}$ (6.4-fold), presumably via functionally intact stimulatory $G_{s}$ proteins. During embryonic and postnatal development, both the absolute basal enzyme activities and stimulated enzyme activities appear to increase in parallel, presumably because of increases in the number of catalytic subunits. However, as shown in parentheses in Table 3, the comparable degree (i.e., percentage) of stimulation above basal at each of the time points indicates that there is little change in the efficiency of $\mathrm{G}_{\mathrm{s}}$-stimulated activity via GTP throughout pre- and postnatal development. $\mathrm{NaF}$ elicited a greater percentage of stimulation in embryonic tissue (i.e., E17, E19) than later in development. This difference, however, was small (6.4- versus 5 -fold at E17 and P28, respectively). In contrast, the ratio of forskolin-stimulated activity to basal levels appears to be somewhat larger between P21 and P28 than that at E17.

Table 2. Mean ( \pm SEM) adenylate cyclase activity for rat pups at ages P3 and P30 $(n=4$ in each group)

\begin{tabular}{|c|c|c|c|c|}
\hline & \multicolumn{4}{|c|}{ Activity (pmol cAMP $/ \mathrm{min} / \mathrm{mg}$ protein) } \\
\hline & \multicolumn{2}{|c|}{ Cortex } & \multicolumn{2}{|l|}{ Striatum } \\
\hline & $\overline{\mathrm{P} 3}$ & P30 & $\overline{\mathbf{P 3}}$ & P30 \\
\hline Basal & $57.8 \pm 5.0$ & $156.1 \pm 13.4$ & $143.2 \pm 16.9$ & $222.7 \pm 29.7$ \\
\hline$+100 \mu \mathrm{M}$ GTP & $113.6 \pm 9.6$ & $229.1 \pm 16.5$ & $227.9 \pm 20.8$ & $314.4 \pm 29.7$ \\
\hline$+\mathrm{GTP}+1 \mu \mathrm{M} \mathrm{CRF}$ & $177.9 \pm 14.4$ & $345.4 \pm 19.1$ & $267.5 \pm 20.0$ & $333.6 \pm 18.0$ \\
\hline Stim. CRF ${ }^{a}(\%)$ & $56.9 \pm 2.5$ & $51.4 \pm 3.1$ & $18.0 \pm 3.3$ & $6.9 \pm 3.5$ \\
\hline
\end{tabular}

${ }^{a}$ Percentage increase with $1 \mu \mathrm{M}$ CRF over the basal $+100 \mu \mathrm{M}$ GTP activity. 

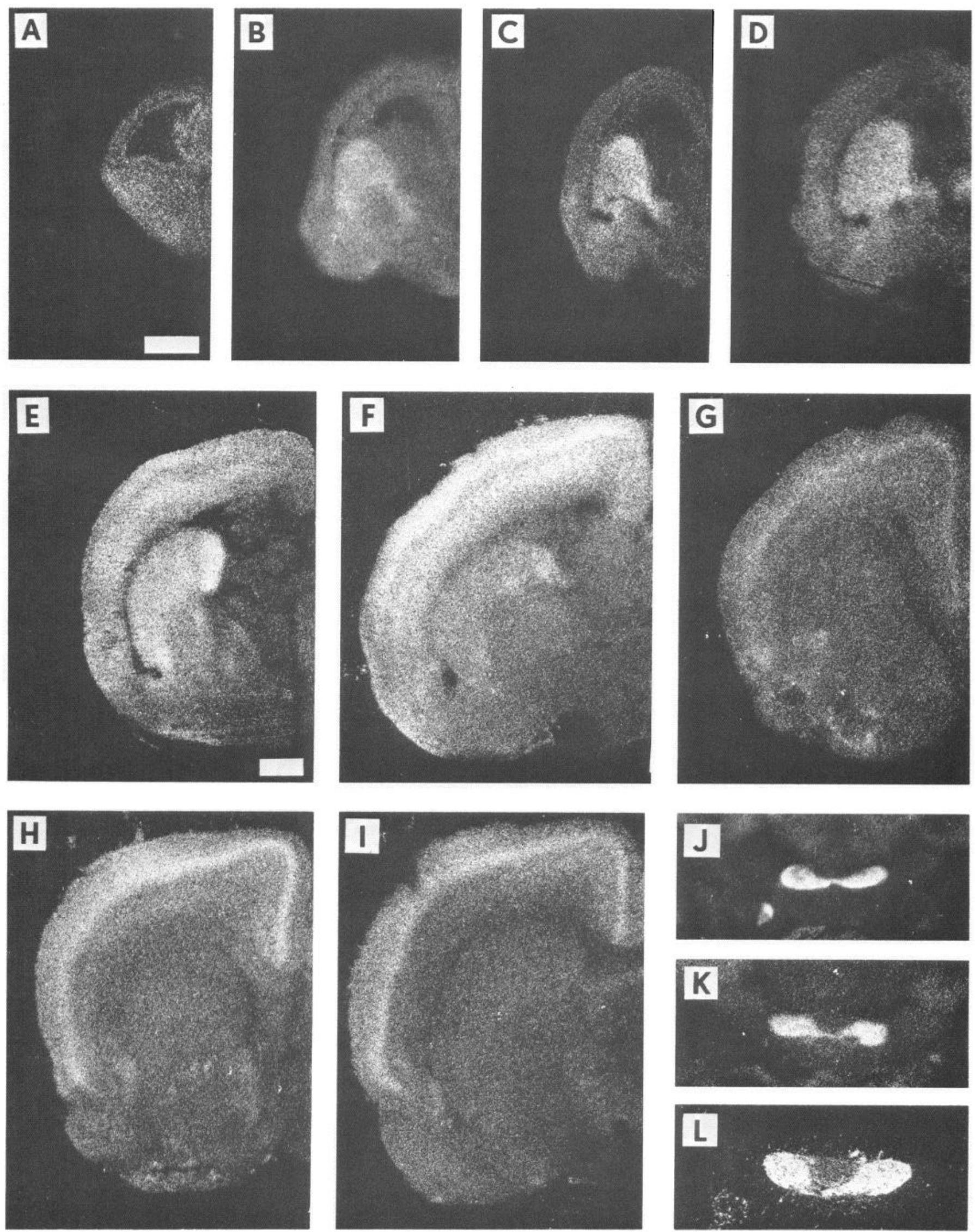

Figure 2. Dark-field autoradiograms of ${ }^{125} \mathrm{I}-\mathrm{Tyr}^{0} \mathrm{-OCRF}$ binding to 16 sections of rat brain from different ages. $A-D$, E15, E17, E19, and E21, all photographed at the same magnification. $E-I, \mathrm{P} 2, \mathrm{P} 8, \mathrm{P} 14, \mathrm{P} 21$, and P28 at the same magnification. $J$, Pituitary E19. $K, \mathrm{Pituitary}$ E21. $L$, Pituitary P14. 
In order to elucidate the developmental patterns of basal and stimulated enzyme activities, we have plotted the values for basal and for absolute stimulation above basal as a percentage of that found in a 28 -d-old rat brain. As shown in Figure 4, at embryonic day 17, basal activity, GTP-, and forskolin-stimulated activities are only $20-30 \%$ of adult values, while NaFstimulated cAMP production is greater than $40 \%$. During preand postnatal development, incrcases in forskolin-stimulated activity closely parallel the increases in basal activity. Since forskolin directly stimulates the catalytic subunit, and the increase in basal activity presumably reflects increases in the number of catalytic subunits, a close developmental parallel in these 2 parameters might be expected. With respect to the ontogeny of $\mathrm{G}_{\mathrm{s}}$-stimulated activity, the pattern is somewhat different with GTP than with NaF as the activator. The absolute amount of GTP-stimulated cAMP production reaches adult values soon after day P8, peaks slightly at day P21, but remains at comparable values between days $\mathrm{P} 8$ and $\mathrm{P} 28$. In contrast, NaFstimulated activity does not attain day P28 values until about day P14, then continues to rise, peaking at $143 \%$ on day $\mathrm{P} 21$ before decreasing to adult levels.

\section{Discussion}

These results demonstrate the early appearance of CRF binding sites in the rat brain, portray a distinct distribution of these receptors during development, and show that these receptors are functionally linked to adenylate cyclase very early in postnatal life.

A previous report (Walker et al., 1986a) described a maximal number of pituitary receptors during the first postnatal weeksimilar to our findings with the brain CRF receptor. Our autoradiographic results demonstrate that, at least in brain, this overshoot results from the expression of receptors in regions (e.g., striatum) where they are relatively inconspicuous in the mature brain. The early appearance and subsequent disappearance of CRF binding in the developing striatum is not easily

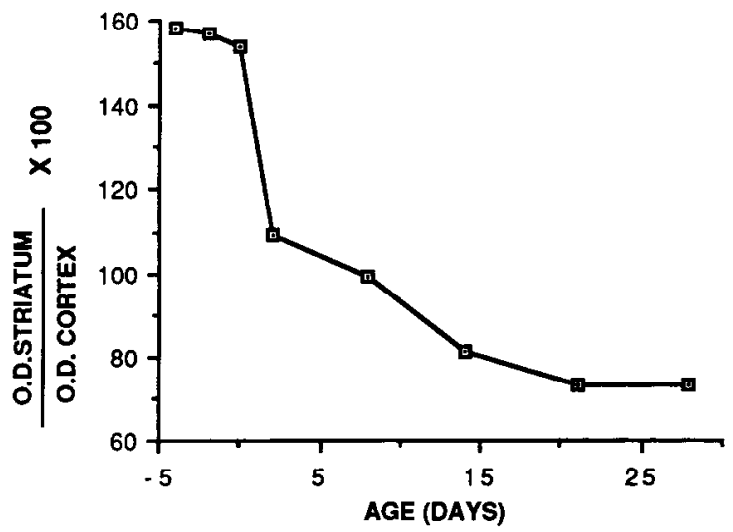

Figure 3. With development, ${ }^{125} \mathrm{I}-\mathrm{Tyr}^{0}-\mathrm{OCRF}$ binding in striatum decreases while binding in cortex increases. The ratio is shown of optical density for autoradiograms across ages E1 7 to P28, comparing striatum to cortex. Much of the binding in striatum appears restricted to the prenatal and very early postnatal period.

explained. These binding sites are lateral to the periventricular germinal zone and are most numerous postnatally, so it is unlikely that CRF is binding to migrating cortical neurons. It is certainly possible that these receptors do not decreasc in number, but change in density as new cell groups migrate in to form the striatal mosaic. Although this possibility may explain the parallel decrease in receptor density in opiate receptors in the striatum (Kent et al., 1981), the absence of the characteristic striatal patches with CRF receptor binding in adults would argue against this explanation for the CRF system. Development might also be expected to increase the quenching of tritiated ligands and thus to artifactually decrease the apparent density of autoradiographic binding. However, the current study used an iodinated ligand for which differential quenching should not be a factor (Kuhar and Unnerstall, 1985).

CRF receptors in the striatum may serve an additional and

Table 3. Ontogeny of the activity of adenylate cyclase and the stimulatory guanine nucleotide regulatory protein in rat brain

\begin{tabular}{llccc}
\multicolumn{5}{l}{ Activity (pmol cAMP/min/mg protein) } \\
\cline { 2 - 5 } Age & Basal & $+100 \mu \mathrm{M} \mathrm{GTP}$ & $+20 \mathrm{mM} \mathrm{NaF}$ & $+10 \mu \mathrm{M}$ Forskolin \\
\hline E17 & $34.8 \pm 2$ & $81.2 \pm 1.3$ & $222 \pm 11$ & $398 \pm 29$ \\
& & $(234 \pm 13)$ & $(638 \pm 5)$ & $(1141 \pm 29)$ \\
E19 & $31.2 \pm 1.5$ & $80.2 \pm 4.7$ & $204 \pm 14$ & $426 \pm 17$ \\
& & $(257 \pm 3)$ & $(652 \pm 21)$ & $(1371 \pm 30)$ \\
E21 & $64.5 \pm 2.3$ & $173.5 \pm 7.9$ & $344 \pm 19$ & $784 \pm 40$ \\
& & $(268 \pm 10)$ & $(532 \pm 15)$ & $(1212 \pm 24)$ \\
P2 & $69.6 \pm 2$ & $221 \pm 2.2$ & $333 \pm 3$ & $768 \pm 24$ \\
& & $(318 \pm 9)$ & $(480 \pm 19)$ & $(1105 \pm 32)$ \\
P8 & $67 \pm 4$ & $212 \pm 14$ & $336 \pm 28$ & $756 \pm 48$ \\
& & $(318 \pm 12)$ & $(499 \pm 15)$ & $(1129 \pm 15)$ \\
P14 & $101 \pm 3$ & $294 \pm 7$ & $573 \pm 33$ & $1392 \pm 51$ \\
& & $(292 \pm 7)$ & $(570 \pm 43)$ & $(1386 \pm 73)$ \\
P21 & $132 \pm 6$ & $338 \pm 14$ & $739 \pm 22$ & $1961 \pm 97$ \\
& & $(255 \pm 6)$ & $(560 \pm 15)$ & $(1481 \pm 91)$ \\
P28 & $120 \pm 5$ & $294 \pm 24$ & $596 \pm 9$ & $1790 \pm 114$ \\
& & $(244 \pm 16)$ & $(498 \pm 26)$ & $(1486 \pm 71)$
\end{tabular}


Figure 4. Development of guanine nucleotide binding protein $\left(G_{s}\right)$ and catalytic subunit from $E 17$ to $P 28$ in whole rat brain homogenates, expressed as percentages of $P 28$ values. Basal rate of cAMP formation represents the unstimulated level. $\mathrm{NaF}$ and forskolin, believed to activate the $\mathrm{G}_{\mathrm{s}}$ and catalytic subunit, respectively, show increasing stimulatory effects, roughly in parallel with the basal level. Absolute values are shown in Table 3.

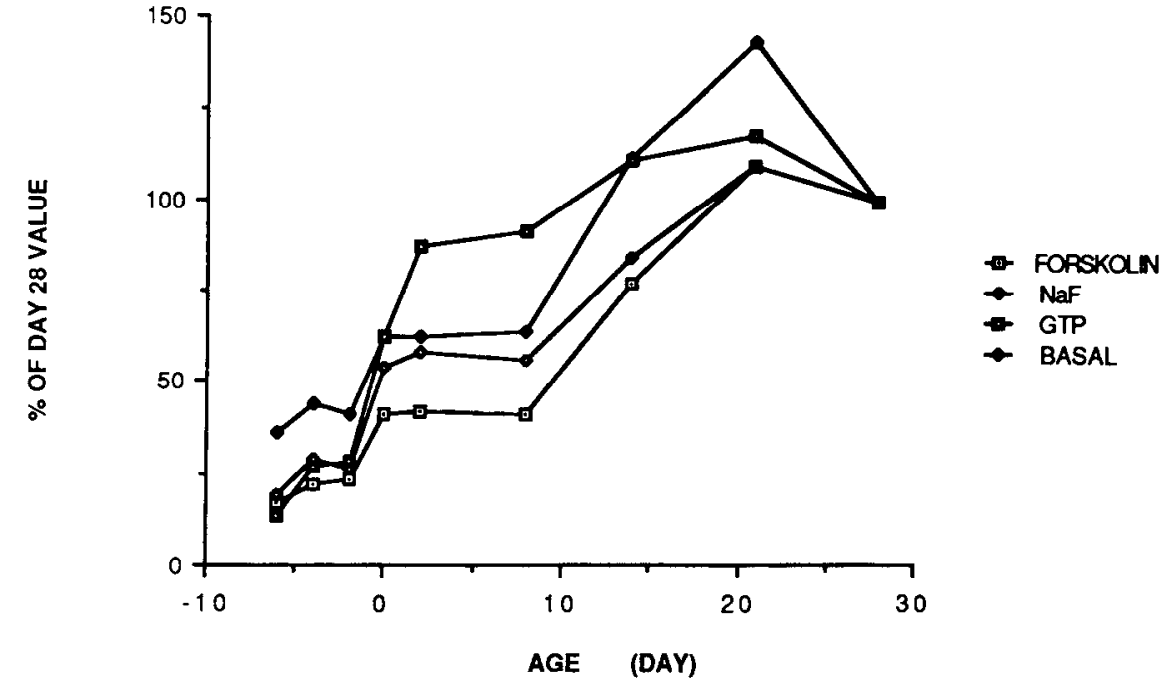

transient developmental role, unrelated to the generation of cAMP (Table 2) and independent of the very marked expression of this receptor in the pituitary. A trophic role for CRF receptors in striatum would be consistent with this developmental pattern, as striatal neurons differentiate and develop synapses just after CRF receptors are maximal (Fentress et al., 1981). Another factor that may contribute to the transient expression of these receptors is the high concentration of CRF produced by the placenta and presumably reaching the developing brain (Goland et al., 1986; Sasaki et al., 1987). In other peptide systems, exposure to high levels of ligand can induce, rather than decrease, receptors, as expected in adulthood (Handelmann, 1985). However, this would not explain why receptors appear only in the striatum or why they fail to appear in cortex until postnatal life.

In contrast to the disappearance of receptors with the differentiation of the striatum, the time of appearance of CRF receptors in the cortex parallels the emergence of dendritic arborization and the increase in synapse formation that occurs postnatally in the rat brain. Although CRF receptors are localized mostly to layer IV in the adult, the initial labeling of the cortex at P2 and P8 appears more diffuse. The apparent overshoot of CRF receptors to values above adult levels at P8 in homogenates probably reflects a diffuse transcortical appearance in the autoradiograms. This may represent a broader undifferentiated distribution prior to the final sculpting of cortical connections, such as axonal collaterals, which takes place in the second and third week of postnatal life.

CRF rcceptors are functionally linked to the guanine nucleotide regulatory protein relatively early in development (roughly in parallel with the expression of cortical receptors), in contrast to other receptors using this second-messenger system. The increased stimulation of $\mathrm{CAMP}$ by $\mathrm{NaF}$ and forskolin during the second postnatal week suggests relatively late expression of these coupling proteins in brain, consistent with an earlier report (Keshles and Levitzki, 1984) using similar methods. Two cautionary notes are in order. First, these methods assess stimulation of cyclase rather than measure $G$ proteins directly. There may be developmental changes in $G_{s}$ or other coupling proteins, such as $G_{i}$, that we could not assess with our functional measures. In addition, it should be noted that when our data are analyzed as percentage increases over baseline cAMP production, there is little change in the functional coupling to receptors across development (Table 3 ). We interpret this difference be- tween the incremental pattern of stimulated levels (Fig. 4) and the relatively invariant percentage increase over baseline as representing changes in baseline levels of the enzyme. The actual time at which receptors become linked to adenylate cyclase might be expected to vary with the type of receptor, the brain region, and the functional importance of the system in development. For instance, serotonin appears to stimulate near-adult levels of cyclase in the colliculi of newborn rats (Enjalbert et al., 1978), whereas dopamine stimulation of cyclase remains below mature levels until the second postnatal week (Pardo et al., 1977; Nomura et al., 1985). With the development of selective probes for these coupling proteins, the regional ontogeny of the different components of this second-messenger system should become evident using in situ hybridization.

As with developmental studies of receptors for monoamines (Harden et al., 1977; Morris et al., 1980), studies of the ontogeny of receptors for several neuropeptides, including opiates (Kent et al., 1981), vasopressin (Petracca et al., 1986), and substance $P$ (Quirion and Dam, 1986), have described high numbers and an altered distribution of receptors in the early postnatal brain. It is not yet clear, however, when these early-appearing peptide receptors become functionally linked to second messengers or ion channels, or whether these fetal brain receptors have a functional role. Perinatal administration of opiates has been associated with acute and long-term behavioral and physiologic effects (Handelmann, 1985) suggesting that, at least for the opiate system, the receptor can affect a response even within the first week of postnatal life. In the case of CRF, however, there are as yet few data to support a physiologic role in the brain during the perinatal period. One study using pharmacologic doses of CRF (10 and $50 \mu \mathrm{g} /$ pup) reported effects on growth and maturation (Zadina and Kastin, 1986); however, these effects might be secondary to the pituitary-mediated corticotrophic role, with the resultant increase in glucocorticoids, rather than a direct central effect of CRF itself. Central administration of CRF to 8-d-old rat pups is associated with dose-dependent behavioral effects, but in a direction opposite to those predicted from adult studies (Insel, in press).

Data from our study do not explain the stress-nonresponsive period during the first 2 weeks after birth in the rat. Throughout this period, the brain CRF receptor appears capable of a fully functional response (Fig. 1), although the CRF activity index does not approach adult levels until day P14. Presumably this 
latter measure is the most accurate for describing the efficiency of the receptor population. However, to test the hypothesis that the CNS role of this peptide involves integrating the stress response during development, further studies concentrating on the synthesis and release of CRF during development will be necessary. In particular, the relationship of the extrahypothalamic CRF pathways to the HPA axis remains unclear. Glucocorticoids potently decrease the response of the pituitary CRF receptor during the first 2 postnatal weeks (Sapolsky and Meaney, 1986). A relationship of glucocorticoids to developing brain $\mathrm{CRF}$ receptors seems unlikely, as circulating levels are low and glucocorticoid receptors in brain do not develop until the second postnatal week (Meaney et al., 1985). Our studies of the brain CRF receptor suggest a development parallel with that of the pituitary CRF receptor (Walker et al., 1986a), but additional evidence for a functional relationship between receptors at these 2 sites is needed.

\section{References}

Aldenhoff, J. B., D. L. Gruol, J. Rivier, W. Vale, and G. R. Siggins (1983) Corticotropin-releasing factor decreases post-burst hyperpolarizations and excites hippocampal pyramidal neurons in vitro. Science 221: 875-876.

Battaglia, G., E. L. Webster, and E. B. De Souza (1987) Characterization of corticotropin-releasing factor (CRF) receptor-mediated adenylate cyclase activity in rat central nervous system. Synapse $1: 572-$ 581.

Britton, D. R., G. F. Koob, J. Rivier, and W. Vale (1982) Intraventricular corticotropin-releasing factor enhances behavioral effects of novelty. Life Sci. 31: 363-367.

Brown, M. R., L. A. Fisher, J. Spiess, C. Rivier, J. Rivier, and W. Vale (1982) Corticotropin-releasing factor: Actions on the sympathetic nervous system and oxygen consumption. Life Sci. 30: 207-210.

Bugnon, C., D. Fellmann, A. Gouget, and J. Cardot (1982) Ontogeny of the corticoliberin neuroglandular system in rat brain. Nature 298: $159-161$.

Bugnon, C., D. Fellmann, A. Gouget, J. L. Bresson, M. C. Clavequin, M. Hadjiyassemis, and J. Cardot (1984) Corticoliberin neurons: Cytophysiology, phylogeny and ontogeny. J. Steroid Biochem. 20: 183-195.

Chen, F. M., L. M. Bilezikjian, M. H. Perrin, J. Rivier, and W. Vale (1986) Corticotropin-releasing factor receptor: Mediated stimulation of adenylate cyclase activity in the rat brain. Brain Res. 381: 49-57.

Cummings, S., R. Elde, J. Ells, and A. Lindall (1983) Corticotropinreleasing factor immunoreactivity is widely distributed within the central nervous system of the rat: An immunohistochemical study. J. Neurosci. 3: 1355-1368.

De Souza, E. B. (1987) Corticotropin-releasing factor receptors in the rat central nervous system: Characterization and regional distribution. J. Neurosci. 7: 88-100.

De Souza, E. B., M. H. Perrin, T. R. Insel, J. Rivier, W. W. Vale, and M. J. Kuhar (1984) Corticotropin-releasing factor receptors in rat forebrain: Autoradiographic identification. Science 224: 1449-1451.

De Souza, E. B., T. R. Insel, M. H. Perrin, J. Rivier, W. W. Vale, and M. J. Kuhar (1985a) Corticotropin-releasing factor receptors are widely distributed within the rat central nervous system: An autoradiographic study. J. Neurosci. 5: 3189-3203.

De Souza, E. B., T. R. Insel, M. H. Perrin, J. Rivier, W. Vale, and M. Kuhar (1985b) Differential regulation of corticotropin-releasing factor receptors in anterior and intermediate lobes of pituitary and in brain following adrenalectomy in rats. Ncurosci. Lett. 56: 121-128.

Dupouy, J. P., and A. Chatelain (1984) In vitro effects of corticosterone, synthetic ovine CRF, and AVP on the release of ACTH by fetal rat pituitary glands. J. Endocrinol. 101: 339-344.

Enjalbert, A., S. Bourgoin, M. Hamon, J. Adrien, and J. Bockaert (1978) Post synaptic serotonin: Sensitive adenylate cyclase in the central nervous system. Mol. Pharmacol. 14: 2-10.

Fentress, J. C., B. B. Stanfield, and W. M. Cowan (1981) Observations on the development of the striatum in rats and mice. Anat. Embryol. 163: 275-298.

Goland, R. S., S. L. Starle, L. S. Brown, and A. G. Frantz (1986) High levels of CRF immunoreactive in maternal and fetal plasma during pregnancy. J. Clin. Endocrinol. Metab. 63: 199-203.

Handelmann, G. (1985) Neuropeptides in development. J. Physiol. (Paris) 80: 268-274.

Harden, T. K., B. B. Wolfe, J. R. Sporn, J. P. Perkins, and P. B. Molinoff (1977) Ontogeny of $\beta$-adrenergic receptors in rat cerebral cortex. Brain Res. 125: 99-108.

Hiroshige, T., and T. Sato (1971) Changes in hypothalamic content of corticotropin-releasing activity following stress during neonatal maturation in the rat. Neuroendocrinology $7: 257-270$.

Insel, T. R., and C. Harbaugh (in press) Central administration of CRF alters rat pup isolation cells. Pharm. Bioch. Behavior.

Insel, T. K., J. A. Aloi, D. Goldstein, J. H. Wood, and J. H. Jimerson (1984) Plasma cortisol and catecholamine responses to intracerebroventricular administration of CRF to rhesus monkeys. Life Sci. 34: 1873-1878.

Kalin, N. H., S. E. Shelton, G. W. Kraemer, and W. E. McKinney (1983) Corticotropin-releasing factor administered intraventricularly to rhesus monkeys. Peptides 4: 217-220.

Kent, J. L., C. B. Pert, and M. Herkenham (1981) Ontogeny of opiate receptors in rat forebrain: Visualization by in vitro autoradiography. Dev. Brain Res. 2: 487-504.

Keshles, O., and A. Levitzki (1984) The ontogenesis of $\beta$-adrenergic receptors and of adenylate cyclase in the developing rat brain. Biochem. Pharmacol. 33: 3251-3253.

Kuhar, M. J., and J. Unnerstall (1985) Quantitative receptor mapping by autoradiography: Some current technical problems. Trends Neurosci. 8: 49-53.

Lowry, O. H., N. J. Rosebrough, A. L. Farr, and R. J. Randall (1951) Protein measurement with the folin phenol reagent. J. Biol. Chem. 193: 265-275.

Meaney, M. I., R. M. Sapolsky, and S. S. McEwen (1985) The development of the glucocorticoid receptor system in the rat limbic brain. I. Ontogeny and autoregulation. Dev. Brain Res. 18: 159-164.

Morris, M. J., J.-P. Dausse, M.-A. Devynck, and P. Meyer (1980) Ontogeny of ${ }_{1}$ and ${ }_{2}$ adrenoreceptors in rat brain. Brain Res. 190: 268-271.

Nomura, Y., J. Makihata, and T. Segawa (1985) Activation of adcnylate cyclase by dopamine, GTP, NaF, and forskolin in striatal membranes of neonatal, adult, and senescent rats. Eur. J. Pharmacol. 106: 437-440.

Pardo, J. R., I. Creese, D. R. Burt, and S. H. Snyder (1977) Ontogenesis of dopamine receptor binding in the corpus striatum of the rat. Brain Res. 125: 376-382.

Petracca, F. M., D. G. Baskin, J. Diaz, and D. Dorsa (1986) Ontogenetic changes in vasopressin binding site distribution in rat brain: An autoradiographic study. Dev. Brain Res. 28: 163-168.

Quirion, R., and T. V. Dam (1986) Ontogeny of substance P receptor binding sites in rat brain. J. Neurosci. 6: 2187-2199.

Sapolsky, R. M., and M. J. Meaney (1986) Maturation of the adrenocortical stress response: Neuroendocrine control mechanisms and the stress hyporcsponsive period. Brain Res. Rev. 11: 65-76.

Sasaki, A., O. Shinkawa, A. N. Margioris, A. Liotta, S. Sato, O. Murakami, G. Meigan, Y. Shimizu, K. Hanew, and K. Yoshinaga (1987) Immunoreactive CRF in human plasma during pregnancy, labor and delivery. J. Clin. Endocrinol. Metab. 64: 224-229.

Smith, M., G. Bisette, T. A. Slotkin, D. L. Knight, and C. B. Nemeroff (1985) Release of corticotropin-releasing factor from rat brain regions in vitro. Endocrinology 118: 1997-2001.

Stanton, M. E., J. Wallstrom, and S. Levine (1987) Maternal contact inhibits pituitary-adrenal stress responses in preweanling rats. Dev. Psychobiol. 20: 131-145.

Sutton, R. E., G. F. Koob, M. I eMoal, J. Rivier, and W. W. Vale (1982) Corticotropin-releasing factor produces behavioral activation in rats. Nature 297: 331-333.

Swanson, L. W., P. E. Sawchenko, J. Rivier, and W. W. Vale (1983) Organization of ovine corticotropin-releasing factor immunoreactive cells and fibers in the rat brain: An immunohistochemical study. Neuroendocrinology 36: 165-186.

Tache, Y., Y. Goto, M. W. Gunion, W. W. Vale, J. Rivier, and M. Brown (1983) Inhibition of gastric acid secretion in rats by intracerebral injection of corticotropin-releasing factor. Science 222:935937.

Vale, W., J. Spiess, C. Rivier, and J. Rivier (1981) Characterization of a 41-residue ovine hypothalamic peptide that stimulates secretion of corticotropin and beta-endorphin. Science 213: 1394-1397. 
Vale, W., C. Rivier, M. R. Brown, J. Spiess, G. Koob, L. Swanson, L. Bilezikjian, F. Bloom, and J. Rivier (1983) Chemical and biological characterization of corticotropin-releasing factor. Recent Prog. Horm. Res. 39: 245-270.

Valentino, R. J., S. L. Foote, and G. Aston-Jones (1983) Corticotropinreleasing factor activates noradrenergic neurons of the locus ceruleus. Brain Res. 270: 363-367.

Walker, C.-D., M. Perrin, W. Vale, and C. Rivier (1986a) Ontogeny of the stress response in the rat: Role of the pituitary and hypothalamus. Endocrinology 118: 1445-1451.

Walker, C.-D., R. M. Sapolsky, M. J. Meaney, W. W. Vale, and C.
Rivier (1986b) Increased pituitary sensitivity to glucocorticoid feedback during the stress nonresponsive period in the neonatal rat. Endocrinology 119: 1816-1821.

Wynn, P. C., R. L. Hauger, M. C. Holmes, M. A. Millan, K. J. Catt, and G. Aguilera (1984) Brain and pituitary receptors for corticotropin releasing factor: Localization and differential regulation after adrenalectomy. Peptides 5: 1077-1084.

Zadina, J., and A. J. Kastin (1986) Neonatal peptides affect developing rats: $\beta$-Endorphin alters nociception and opiate receptors, $C R F$ alters corticosterone. Dev. Brain Res 29: 21-29. 